\title{
SOVEREIGN BOND SPREADS IN THE EMU PERIPHERAL COUNTRIES: THE ROLE OF THE OUTRIGHT MONETARY TRANSACTIONS
}

\section{Wojciech Grabowski, Ewa Stawasz*}

\begin{abstract}
The paper examines determinants of sovereign bond spreads (in relation to Germany) of the peripheral euro area countries in the period 2007Q3-2015Q3. The study indicates that the introduction of the Outright Monetary Transactions (OMTs) by theECB in the third quarter of 2012 led to a change in the sensitivity of the spreads to the developments of certain macroeconomic fundamentals of these economies. In particular, the ratio of public debt to GDP, which significantly and strongly determined the spreads in the period 2007Q3-2012Q2, proved to be insignificant in the period 2012Q3-2015Q3. In addition, the counterfactual analysis carried out shows that the spreads in the analysed countries would have been much higher if the ECB had not decided to introduce this programme.
\end{abstract}

Keywords: government bond yield spreads, sovereign debt crisis, OMT programme JEL Classification: C23, F33, F36

\section{Introduction}

The global economic and financial crisis, which was triggered off in the summer of 2007 by the panic on the inter-bank loan market in the United States, spilled over to other markets and economies. In spring 2010, it took the form of a debt crisis among some euro area economies. In particular, the peripheral countries of the euro area (Greece, Ireland, Italy, Portugal and Spain) saw their deficits and debts growing, which was accompanied by a sharp rise in their government bond yields (Louzek, 2015).

In analysing the performance of government bond yields of the peripheral euro area countries since 1997 (Figure 1), one can distinguish three phases. During the first decade of the euro, a strong convergence of the yields was observed. The existence of the euro area reduced the risk premium and lessened differences between the yields, even though bond issuers differed significantly with regard to fiscal fundamentals. During the euro area sovereign debt crisis, which we distinguish as the second phase, yields - as for developed countries - became abnormally large. In the third phase, a substantial decrease in the yields of the analysed countries was recorded. We identify its beginning with the announcement of the Outright Monetary Transactions (henceforth OMT) by the European Central Bank (ECB) in the summer of 2012.

* Wojciech Grabowski, Department of Econometric Models and Forecasts, Faculty of Economics and Sociology, University of Lodz, Lodz, Poland (emfwog@uni.lodz.pl);

Ewa Stawasz, Department of International Economics, Faculty of Economics and Sociology, University of Lodz, Lodz, Poland (ewa.stwasz@gmail.com).

The authors gratefully acknowledge the contribution of the anonymous reviewers whose comments have enabled a significant improvement in the earlier version of the paper. The paper was written with the financial support of National Science Centre, Poland, under Grant No. 2015/17/N/HS4/02921. 
Figure 1 | Performance of 10-year Government Bond Yields of the Euro Area Peripheral Countries and Germany

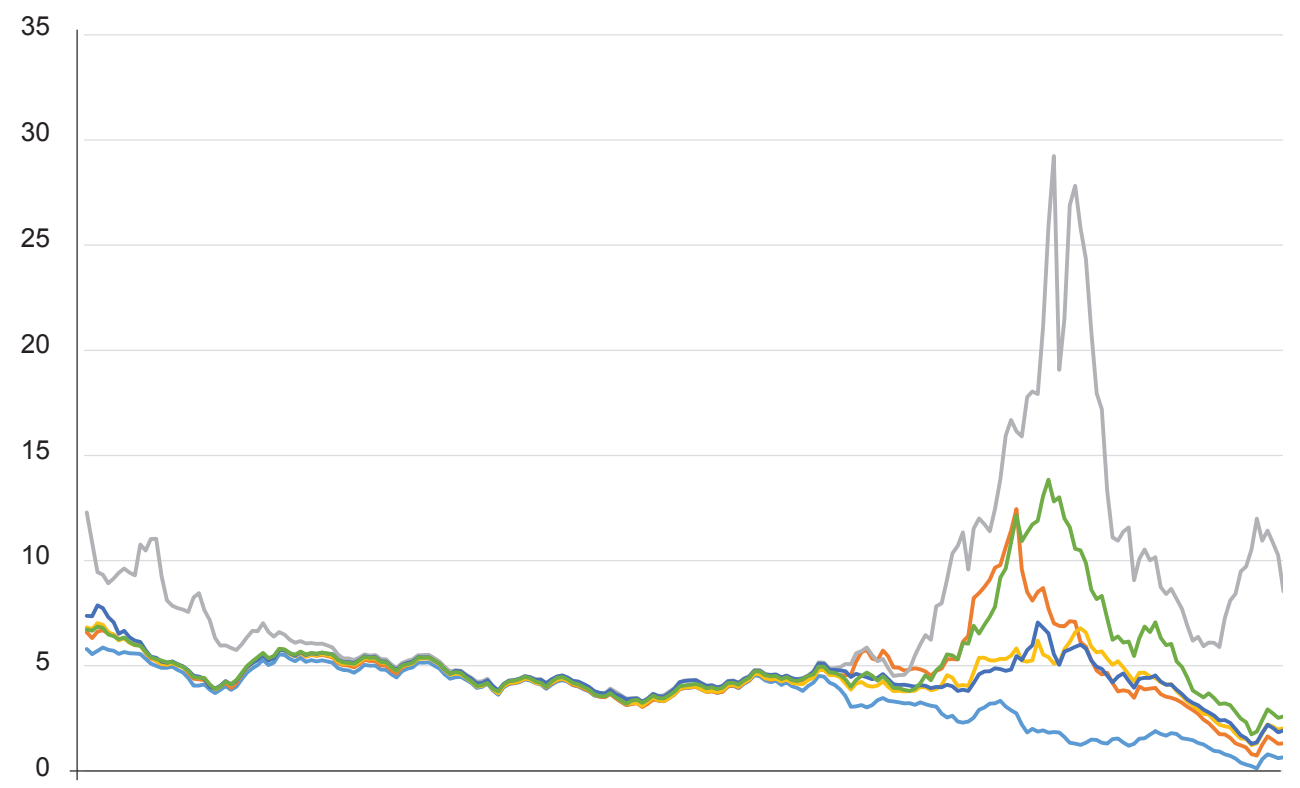

1997M01 1998M07 2000M01 2001M07 2003M01 2004M07 2006M01 2007M07 2009M01 2010M07 2012M01 2013 M07 2015M01

Greece Italy Spain - Portugal — Ireland - Germany

Source: Eurostat

The aim of our study is to identify and compare determinants of long-term government bond spreads of the peripheral euro area countries (vis-à-vis the German Bunds) in two sub-periods - before the introduction of the OMT programme (2007Q3-2012Q2) and after it (2012Q3-2015Q3). Due to the fact that the third quarter of 2012, in which the announcements related to the OMT took place, demarcates the sub-periods highlighted in the study, it is worth recalling the most important features of this programme.

Technical details of the OMT programme were made public on 6 September 2012. Nevertheless, its announcement can be associated with the speech of ECB President Mario Draghi at the conference of investors in London on 26 July 2012. He said then that the ECB would do anything - within its mandate - to preserve the integrity of the euro area (the famous whatever it takes speech). The main premises of the OMT programme contain provisions for conducting unlimited purchases of government bonds of the countries of the European Monetary Union (EMU) that are committed to take appropriate economic reforms. The purchase is to be conducted only in the secondary market and can apply only to government bonds whose maturity does not exceed 3 years. Many economists (see e.g. De Grauwe and Ji, 2014; Winkler, 2015) identify the introduction of the OMT programme with the ECB taking on the role of lender of last resort for the governments of the EMU countries. Its unlimited nature (in contrast to the previous ECB's programme - the SMP programme) is particularly emphasised in this context. 
The impact of the introduction of the OMT programme on sovereign bond yields of the EMU countries was the subject of the previous research. Its effectiveness in reducing the yields was confirmed, among others, by M. Falagiarda and S. Reitz (2015) (for Italy, Spain and - to a smaller extent - Portugal) as well as Kilponen et al. (2015) (all the peripheral EMU countries). The cited studies demonstrated its short-term impact (the analysis was conducted in the event windows of 2, 3 and 5 days). Long-term effects of the OMT programme in the form of reduced bond yields were confirmed in the works of De Grauwe and Ji (2014) as well as Saka et al. (2015). However, the authors of these studies did not attempt to examine whether and - if so - to what extent the parameters reflecting the effect of macroeconomic fundamentals on the yields changed under the programme compared to the period of crisis until the second quarter of 2012. Thus, despite the large body of literature on the subject of determinants of government bond yields of the euro area countries, we see a gap that we wish to address. At the same time, in contrast to the above-mentioned authors, we have a sufficiently large number of observations (since the OMT programme has been in place for more than 3 years), which allows us to carry out appropriate research.

The remainder of the paper is as follows. Section 2 gives an overview of the related literature. Section 3 describes data and provides the specification of the econometric model. Section 4 presents the results of the empirical research aimed at identifying the factors that shaped the spreads. Section 5 concludes the paper.

\section{Literature Overview}

Since the beginning of the crisis, a number of studies devoted to determinants of government bond yields of the EMU countries have been conducted. The studies vary in terms of the period of analysis, the group of countries, the frequency of data and the applied research method. In most of the research, as in our study, the spread between the 10-year government bond yields of individual euro area countries and the yields of the corresponding German government bonds was adopted as the dependent variable. In particular, we can distinguish the following directions of research.

Firstly, many of the authors focus on the role of fundamental and non-fundamental factors in explaining the spreads in the two sub-periods - before the crisis and after its beginning. The conclusions of these studies indicate that the impact of the variables making up the two groups changed over time. In the period before the crisis, investors did not pay attention to the differences in the variables reflecting the economic situation (including in particular fiscal standing and international competitiveness) of individual euro area countries, considering bonds issued by those countries as close substitutes. Variables approximating the global aversion to risk (for example VIX) proved to be significant instead (see e.g. Giordano et al., 2013; De Grauwe and Ji, 2013; Oliveira, 2012). In times of crisis, in the conditions of strong risk aversion, there was a significant increase in the role of fundamental factors in explaining the yields. In this context, Giordano et al. (2013) as well as Beirne and Fratzscher (2013) point to the phenomenon of wake-up-call contagion, which refers to an increase in sensitivity of investors to worse macroeconomic fundamentals of the peripheral euro area countries after the disclosure of debt problems of Greece.

The second group of research concerns the sensitivity of yields of the crisis-affected countries to credit rating announcements as well as macroeconomic and political news. Numerous analyses indicate that: 
- $\quad$ rating downgrades and negative news had a stronger impact on the yields than rating upgrades and positive news (see e.g. Alsaaka and Gwilym, 2013; Beetsma et al., 2013);

- $\quad$ during the euro area sovereign debt crisis, rating downgrades and negative news from Greece had a negative impact on government bond yields in other crisis-affected countries (see e.g. Aizenman et al., 2013).

Thirdly, a great deal of attention is devoted to the impact of anti-crisis policy implemented by the institutions of the EU during the euro area debt crisis, with particular focus on the ECB's measures. For example, Kilponen et al. (2015) examine the impact of initiatives undertaken by the ECB within the framework of enhanced credit support and the two asset purchase programmes directly targeted at the situation in the government bond market - the SMP and OMT. The authors show that the announcement of the SMP and OMT programmes as well as the whatever it takes speech had a major negative impact on spreads (vis-à-vis the 10-year euro swap rate) in all the countries analysed (the peripheral EMU countries, as well as Germany and France). The highest (in terms of the absolute value) estimates of the parameters were obtained for Spain and Italy; slightly lower, but also statistically significant, for Greece, Ireland and Portugal. Similar studies were conducted by Falagiarda and Reitz (2015). They confirm the effectiveness of the announcements on the SMP and OMT programmes in reducing the spreads between the yields on government bonds of the peripheral EMU countries and the German yields (in the case of the OMT programme, the relationship was demonstrated for Spain and Italy, and - to a lesser extent - for Portugal). Altavilla et al. (2014), who focussed only on the impact of the OMT programme, proved that the announcements associated with it significantly reduced the government bond yields of Spain and Italy (by approximately 200 and 100 basis points for 2-year and 10-year maturity bonds, respectively). In the case of the other two countries which the authors considered in the study, i.e. Germany and France, the impact of those announcements proved to be statistically insignificant. The cited above studies allow to draw conclusions concerning only short-term effects of the announcements on the ECB's programmes (the analyses were carried out in the event windows of a few days).

Long-term effects of the announcement of the OMT programme were, among others, confirmed in the studies of De Grauwe and Ji, 2014; Altavilla et al., 2014; ${ }^{1}$ and Saka et al., 2015. As indicated by the first of these authors, a marked decline in government bond yields in the peripheral EMU countries since the third quarter of 2012 did not result from improving their macroeconomic fundamentals, but was determined by positive market sentiment. The improvement in the sentiment in the government bond market of the euro area coincided with the announcement of the OMT programme. Similar conclusions can be drawn from the study by Saka et al. (2015), who showed that market perception of overall euro area credit risk decreased under the OMT programme. Altavilla et al. (2014) show that in the months following the announcement of the OMT programme, there was a decline in government bond yields, the overall situation in the financial markets improved, and the dependence of the euro area banking system on the Eurosystem's refinancing decreased. They attribute a part of these improvements to the announcement of the OMT programme.

Taking as the starting point the conclusions of the previous studies on the role of the OMT programme in easing tensions in the EMU government bond market, we seek

1 The authors studied both the short-term impact of the introduction of the OMT programme on the yields as well as its long-term impact on economic variables. 
to estimate the change in sensitivity of bond yields of the peripheral EMU countries to changes in selected macroeconomic fundamentals which occurred after the announcement of the programme. It seems that such a study may be carried out only at present (i.e. more than three years after the announcement of the OMT programme) due to the appropriate sample size. In addition, in order to determine what the role of these variables would have been in explaining the spreads, if the ECB had not introduced the OMT programme, we conduct a counterfactual analysis. It allows to examine how government bond yields of the countries analysed would have reacted in the absence of the institution of the lender of last resort for the governments in the euro area.

\section{Data Description and Preliminary Statistics}

A set of potential determinants of government bond yields, and consequently spreads, was constructed on the basis of the conducted literature studies. It was also determined by data availability. In particular, it takes into account the following variables:

1. Public debt as percentage of GDP (Debt). An increase in this ratio results in the deterioration of country risk assessment. Thus, the expected sign of the estimate of the parameter for this variable is positive.

2. Projected (1 year ahead) fiscal budget to GDP ratio $\left(D e f^{e}\right)$. The projected rather than current deficit to GDP ratio is often used in research on determinants of government bond yields (in the case of euro area countries, this variable was taken into account by, among others: Arghyrou and Kontonikas, 2012, as well as Bernoth and Erdogan, 2012). The proposed approach reflects the forward looking behaviour of financial markets. The expected sign of the estimate of the parameter for $D e f^{e}$ is negative.

3. Rate of economic growth (Growth). The expected sign of the estimate of the parameter for this variable is negative. Positive GDP growth is conducive to the fulfilment of payment obligations. Along with a decline in economic growth of the given country, its ability of tax collection decreases, making it difficult to service debt. Consequently, country risk assessment may deteriorate. At the same time, it should be noted that an increase in debt is not likely to lead to greater financial risk, if it is slower than GDP growth.

4. Current account balance as per cent of GDP $(C A)$. In the case of the analysed variable, the direction of its impact on the yields is ambiguous. The current account surplus/deficit is a measure of the given country's international competitiveness. Countries that record high current account deficits are seen as less competitive in terms of exports. Given the above, the negative estimate of the parameter for $C A$ can be expected. However, if high current account deficits are related to FDI inflows which in the future should be conducive to higher economic growth, then a reverse sign of the estimate of the parameter can be expected. Moreover, according to the balance of payments identity, a current account surplus is mirrored by a capital account deficit. Net capital export may, for example, reflect the country's inability to obtain foreign loans or capital outflows, increasing credit default risk. In this case, it can be expected that the sign of the estimate of the parameter for this variable will be positive.

5. Inflation (Infl) A higher growth rate of prices in the given country compared to the rate observed among its trading partners is likely to result in the deterioration of its competitiveness. This applies particularly to the countries that make up a currency union. They cannot improve price competitiveness of their exports through de- 
valuation of their national currency. They must therefore initiate other flexibility mechanisms, e.g. lower wages (De Grauwe, 2012). However, such mechanisms may be difficult to implement, as shown by the case of the peripheral euro area countries during the crisis. Moreover, in anticipation of acceleration in prices, investors will demand a higher interest rate. Thus, the expected sign of the estimate of the parameter for this variable is positive.

6. European Economic Policy Uncertainty Index (EPU). In studies on changes in government bond yields, apart from variables characterising the condition of the issuer, variables reflecting the situation in the world economy, or in a specific region, are also taken into account. For example, the CBOE Volatility Index (VIX) is very often used as the variable approximating the global risk aversion (it was used in studies on changes in government bond yields in the euro area by, among others: Arghyrou and Kontonikas, 2012 as well as Giordano et al., 2014). We decided to include in this study a variable that more closely reflects the situation in the euro area than in the US economy. For this purpose, the index of European EPU, whose values depend on the number of macroeconomic news pointing to the uncertain economic situation, is considered. The expected sign of the estimate of the parameter for this variable is positive.

Table 1 | Descriptive Statistics for Consecutive Variables - Means and Standard Deviations (in brackets)

\begin{tabular}{|c|c|c|c|c|c|c|c|c|c|c|}
\hline \multirow{2}{*}{ Variable } & \multicolumn{2}{|c|}{ Greece } & \multicolumn{2}{|c|}{ Ireland } & \multicolumn{2}{|c|}{ Italy } & \multicolumn{2}{|c|}{ Portugal } & \multicolumn{2}{|c|}{ Spain } \\
\hline & $\begin{array}{c}\text { 2007Q3- } \\
2012 Q 2\end{array}$ & $\begin{array}{c}\text { 2012Q3- } \\
\text { 2015Q3 }\end{array}$ & $\begin{array}{c}2007 Q 3- \\
2012 Q 2\end{array}$ & \begin{tabular}{|c|}
$2012 Q 3-$ \\
$2015 Q 3$
\end{tabular} & $\begin{array}{c}2007 Q 3- \\
2012 Q 2\end{array}$ & $\begin{array}{c}\text { 2012Q3- } \\
2015 Q 3\end{array}$ & $\begin{array}{c}2007 Q 3- \\
2012 Q 2\end{array}$ & $\begin{array}{c}\text { 2012Q3- } \\
2015 Q 3\end{array}$ & $\begin{array}{c}2007 Q 3- \\
2012 Q 2\end{array}$ & $\begin{array}{c}\text { 2012Q3- } \\
\text { 2015Q3 }\end{array}$ \\
\hline Yields & $\begin{array}{c}6.83 \\
(7.60)\end{array}$ & $\begin{array}{c}9.53 \\
(4.68)\end{array}$ & $\begin{array}{c}3.07 \\
(2.63)\end{array}$ & $\begin{array}{c}1.81 \\
(1.13)\end{array}$ & $\begin{array}{c}1.62 \\
(1.34)\end{array}$ & $\begin{array}{c}2.26 \\
(0.96)\end{array}$ & $\begin{array}{c}3.46 \\
(3.86)\end{array}$ & $\begin{array}{c}3.84 \\
(2.01)\end{array}$ & $\begin{array}{c}1.52 \\
(1.36)\end{array}$ & $\begin{array}{c}2.40 \\
(1.27)\end{array}$ \\
\hline Debt & $\begin{array}{c}58.36 \\
(16.23)\end{array}$ & $\begin{array}{l}94.32 \\
(9.30)\end{array}$ & $\begin{array}{c}-3.89 \\
(24.89)\end{array}$ & $\begin{array}{l}38.38 \\
(6.45)\end{array}$ & $\begin{array}{l}38.82 \\
(2.41)\end{array}$ & $\begin{array}{l}54.11 \\
(6.77)\end{array}$ & $\begin{array}{c}16.10 \\
(12.24)\end{array}$ & $\begin{array}{l}53.15 \\
(4.34)\end{array}$ & $\begin{array}{c}-19.57 \\
(7.84)\end{array}$ & $\begin{array}{c}17.67 \\
(8.77)\end{array}$ \\
\hline Defe & $\begin{array}{l}-3.54 \\
(1.29)\end{array}$ & $\begin{array}{l}-1.02 \\
(0.98)\end{array}$ & $\begin{array}{l}-7.60 \\
(1.10)\end{array}$ & $\begin{array}{l}-6.93 \\
(0.90)\end{array}$ & $\begin{array}{c}6.44 \\
(0.46)\end{array}$ & $\begin{array}{c}7.48 \\
(0.10)\end{array}$ & $\begin{array}{c}-4.16 \\
(1.15)\end{array}$ & $\begin{array}{l}-2.18 \\
(0.96)\end{array}$ & $\begin{array}{l}-4.17 \\
(1.94)\end{array}$ & $\begin{array}{l}-3.38 \\
(0.56)\end{array}$ \\
\hline$C A$ & $\begin{array}{c}-17.78 \\
(3.44)\end{array}$ & $\begin{array}{l}-8.95 \\
(1.91)\end{array}$ & $\begin{array}{l}-9.21 \\
(2.56)\end{array}$ & $\begin{array}{l}-4.11 \\
(1.86)\end{array}$ & $\begin{array}{l}-8.48 \\
(0.84)\end{array}$ & $\begin{array}{l}-5.82 \\
(0.68)\end{array}$ & $\begin{array}{c}-15.10 \\
(3.00)\end{array}$ & $\begin{array}{l}-6.46 \\
(1.36)\end{array}$ & $\begin{array}{c}-11.28 \\
(3.17)\end{array}$ & $\begin{array}{l}-5.91 \\
(1.02)\end{array}$ \\
\hline InfI & $\begin{array}{c}0.88 \\
(0.97)\end{array}$ & $\begin{array}{l}-1.32 \\
(0.52)\end{array}$ & $\begin{array}{l}-0.75 \\
(0.85)\end{array}$ & $\begin{array}{l}-0.33 \\
(0.31)\end{array}$ & $\begin{array}{c}0.32 \\
(0.35)\end{array}$ & $\begin{array}{l}-0.06 \\
(0.44)\end{array}$ & $\begin{array}{c}0.05 \\
(0.55)\end{array}$ & $\begin{array}{l}-0.35 \\
(0.54)\end{array}$ & $\begin{array}{c}0.32 \\
(0.52)\end{array}$ & $\begin{array}{l}-0.22 \\
(0.58)\end{array}$ \\
\hline Growth & $\begin{array}{l}-0.05 \\
(0.06)\end{array}$ & $\begin{array}{l}-0.03 \\
(0.02)\end{array}$ & $\begin{array}{l}-0.01 \\
(0.03)\end{array}$ & $\begin{array}{c}0.03 \\
(0.03)\end{array}$ & $\begin{array}{l}-0.02 \\
(0.01)\end{array}$ & $\begin{array}{l}-0.02 \\
(0.01)\end{array}$ & $\begin{array}{l}-0.02 \\
(0.03)\end{array}$ & $\begin{array}{l}-0.01 \\
(0.02)\end{array}$ & $\begin{array}{l}-0.02 \\
(0.03)\end{array}$ & $\begin{array}{l}-0.01 \\
(0.02)\end{array}$ \\
\hline \multirow{2}{*}{ EPU } & \multicolumn{5}{|c|}{ 2007Q3-2012Q2 } & \multicolumn{5}{|c|}{ 2012Q3-2015Q3 } \\
\hline & & & $26.28(9.76$ & & & \multicolumn{5}{|c|}{15.09 (1.77) } \\
\hline
\end{tabular}

Source: Our own calculations

Due to the fact that we are interested in the spreads since the beginning of the recent crisis, the study is conducted for the period of 2007Q3-2015Q3. The lower boundary applies to the first signs of tensions in the financial markets in the United States and the euro area (August 2007). The choice of the upper boundary is conditional on the availability of data 
at the time of the study. For each variable we take end of quarter values. Most of the data come from the Eurostat and OECD databases. The EPU comes from the website http:// www.policyuncertainty.com.

Table 1 shows descriptive statistics for the variables included in the model. Table 2 presents estimates of the parameters for the time variable in the linear trend equations of the selected variables for all the countries. The data in Table 2 show that the reversal of the trend for the spreads in the second sub-period was not accompanied by the corresponding reversal of the trend for the public debt to GDP ratio. Only in the case of Ireland, the sign of the estimate of the parameter for the time variable changed. In the case of Portugal and Greece, a slight decline in the estimate of the parameter was observed, while in the case of Spain and Italy its increase was recorded. As for $C A$ and $D e f^{e}$, the trend change occurred only in some of the countries taken into account. Based on this brief analysis, it can be assumed that the relationship between the variables reflecting the macroeconomic situation of the peripheral EMU countries and the spreads may have differed significantly in the two sub-periods. Therefore, it seems reasonable to verify whether the relationship between the spreads and other variables following the introduction of OMT programme changed.

Table 2 | Estimates of Parameters for the Time Variable in the Linear Trend Equation

\begin{tabular}{|c|c|c|c|c|c|c|c|c|}
\hline \multirow[b]{2}{*}{ Country } & \multicolumn{2}{|c|}{ Debt } & \multicolumn{2}{|c|}{ Defe } & \multicolumn{2}{|c|}{$C A$} & \multicolumn{2}{|c|}{ Yields } \\
\hline & $\begin{array}{c}\text { 2007Q3- } \\
2012 Q 2\end{array}$ & $\begin{array}{c}2012 Q 3- \\
2015 Q 3\end{array}$ & $\begin{array}{c}2007 Q 3- \\
2012 Q 2\end{array}$ & $\begin{array}{c}2012 Q 3- \\
2015 Q 3\end{array}$ & $\begin{array}{c}2007 Q 3- \\
2012 Q 2\end{array}$ & $\begin{array}{c}2012 Q 3- \\
2015 Q 3\end{array}$ & $\begin{array}{c}\text { 2007Q3- } \\
2012 Q 2\end{array}$ & $\begin{array}{c}\text { 2012Q3- } \\
2015 Q 3\end{array}$ \\
\hline Greece & 2.44 & 1.80 & -0.15 & -0.17 & 0.49 & 0.08 & 1.16 & -0.62 \\
\hline Ireland & 4.17 & -1.38 & -0.40 & 0.14 & 0.29 & 0.21 & 0.40 & -0.27 \\
\hline Italy & 0.07 & 1.70 & 0.03 & -0.05 & -0.02 & 0.02 & 0.19 & -0.24 \\
\hline Portugal & 1.94 & 0.99 & 0.00 & 0.01 & 0.42 & -0.08 & 0.58 & -0.48 \\
\hline Spain & 1.26 & 2.15 & -0.29 & 0.18 & 0.45 & -0.16 & 0.21 & -0.31 \\
\hline
\end{tabular}

Source: Our own calculations

In order to verify whether there was a structural change in the third quarter of 2012, the Chow test for structural stability of parameters is conducted. Value of the F statistic for the Chow breakpoint test equals 16.14 ( $p$-value $=0.000)$, which means that the H0 hypothesis about the stability of the long-run relation is rejected.

Thus, based on the Chow test results, we propose the following specification of the model taking into account the interaction terms:

$$
\begin{aligned}
& \text { Yields }_{i t}=\alpha_{0}+\alpha_{1} \text { Debt }_{i t}+\alpha_{1}^{*} \text { Debt }_{i t} O M T_{t}+\alpha_{2} \text { Def }_{i t}^{e}+\alpha_{2}^{*} \text { Def }_{i t}^{e} O M T_{t}+\alpha_{3} \text { Growth }_{i t}+ \\
& +\alpha_{3}^{*} \text { Growth }_{i t} O M T_{t}+\alpha_{4} C A_{i t}+\alpha_{4}^{*} C A_{i t} O M T_{t}+\alpha_{5} \text { Infl }_{i t}+\alpha_{5}^{*} \text { Infl }_{i t} O M T_{t}+\alpha_{6} \text { EPU }_{t}+ \\
& +\alpha_{6}^{*} E P U_{t} O M T_{t}+\varepsilon_{i t} .
\end{aligned}
$$

$2 \quad$ The level as well as the square of Debt were taken into account in order to verify whether in the analysed group of countries "credit punishing effects" consisting in a non-linear increase in the yields under the conditions of rising debt level (Bayoumi, 1995) occurred. A similar approach is applied in the studies of, for example: De Grauwe and Ji (2013), Bernoth et al. (2012). Squared Debt variable proved to be insignificant and, therefore, is not included in the final specification. 
All the variables (except for EPU and OMT) denote differences between the values for individual countries and the corresponding values for Germany. The country and the time period are denoted by $i$ and $t$ respectively.

Yields $s_{i t} \quad$ interest rate on 10-year government bonds,

Debt $_{i t} \quad$ ratio of general government debt to GDP,

$D e f_{i t}^{e} \quad$ projected general government balance for one year ahead (\% of GDP),

$C A_{i t} \quad$ the ratio of current account balance to GDP,

Infl $_{i t} \quad$ inflation rate,

Growth $_{i t}$ yearly percentage change of the real GDP,

$E P U_{t} \quad$ the value of European Economic Policy Uncertainty Index,

$O M T_{t} \quad$ dummy variable, which takes on value 1 from the third quarter of 2012 and 0 before the announcement of the OMT programme.

In order to select the appropriate method of estimation of the parameters of the model (1), panel stationarity tests and the poolability test are carried out. Table 3 shows the results of testing of the order of integration. As it can be seen, Yields variable as well as most of the explanatory variables are integrated of order 1 . This means that there may exist longrun cointegration relationships between these variables.

Table 3 | Testing Order of Integration for Consecutive Variables Using ADF-Fisher and PP-Fisher Test (p-values in brackets)

\begin{tabular}{|c|c|c|c|c|c|}
\hline \multirow{2}{*}{ Variable } & \multicolumn{2}{|c|}{ ADF-Fisher } & \multicolumn{2}{|c|}{ PP-Fisher } & \multirow{2}{*}{ Decision } \\
\hline & Level & 1-st difference & Level & 1-st difference & \\
\hline Yields & $4.67(0.91)$ & $35.78(0.00)$ & $7.13(0.70)$ & $35.78(0.00)$ & $\mathrm{I}(1)$ \\
\hline Debt & $3.61(0.96)$ & $104.11(0.00)$ & $3.41(0.97)$ & $106.45(0.00)$ & $\mathrm{I}(1)$ \\
\hline Def & $27.07(0.00)$ & - & $28.91(0.00)$ & - & $\mathrm{I}(0)$ \\
\hline$C A$ & $8.18(0.61)$ & $200.97(0.00)$ & $7.38(0.69)$ & $201.31(0.00)$ & $\mathrm{I}(1)$ \\
\hline InfI & $10.26(0.42)$ & $89.26(0.00)$ & $12.14(0.28)$ & $89.50(0.00)$ & $\mathrm{I}(1)$ \\
\hline \multirow[t]{2}{*}{ Growth } & $14.34(0.16)$ & $111.09(0.00)$ & $16.46(0.09)$ & $112.30(0.00)$ & $\mathrm{I}(1)$ \\
\hline & \multicolumn{2}{|c|}{ ADF } & \multicolumn{2}{|c|}{ PP } & \\
\hline \multirow{2}{*}{$E P U$} & Level & 1-st difference & Level & 1-st difference & \\
\hline & $-2.61(0.09)$ & $-6.51(0.00)$ & $-2.48(0.12)$ & $-7.07(0.00)$ & $\mathrm{I}(1)$ \\
\hline
\end{tabular}

Source: Our own calculations

In order to find this stationary relationship between the spreads and other economic categories, such methods of estimation as Dynamic OLS or Fully Modified OLS can be used. Their use, however, requires stability of cointegrating relations. Therefore, it should be verified whether the relationship between the spreads and their determinants is the same for each country (see Bun et al. 2004). Value of the F statistic for the poolability test equals 8.28 ( $p$-value $=0.000)$, which means that there are substantial differences in long-run 
estimates between the countries. An appropriate method of estimation should take these differences into account. In order to verify whether the relationships between the spreads and other economic categories are long-run cointegrating relationships, the Pedroni panel cointegration test is conducted (2001). The resulting value of statistic is 2.33 ( $p$-value $=0.02$ ), which means that at the 0.05 level of significance the null hypothesis of the absence of cointegrating relationships must be rejected. We find cointegrating relationships using the Panel Variable Coefficient Model (see Swammy, 1970).

\section{Results of Empirical Investigation}

In the literature on government bond yields of the peripheral EMU countries there is no consensus whether the sudden increase which followed the beginning of the Greek crisis was a manifestation of an adequate response of investors to the worsening macroeconomic fundamentals (especially fiscal fundamentals) of these economies or resulted from other factors. Our research is part of this debate.

Table 4 | Results of the Estimation of the Parameters of the Panel Variable Coefficient Model

\begin{tabular}{|l|c|c|c|c|c|c|}
\hline \multirow{2}{*}{ Variable } & \multicolumn{5}{|c|}{ within } & \multirow{2}{*}{ Random } \\
\cline { 2 - 6 } & Greece & Ireland & Italy & Portugal & Spain & \\
\hline Cons & -3.09 & $6.52^{* *}$ & 0.41 & 6.08 & $5.19^{* * *}$ & 2.46 \\
\hline Debt & $0.25^{* * *}$ & $0.08^{* * *}$ & 0.01 & $0.08^{*}$ & $0.20^{* * *}$ & $0.12^{* *}$ \\
\hline OMT ${ }^{*}$ Debt & $-0.16^{* * *}$ & $-0.09^{* * *}$ & $-0.02^{*}$ & $-0.09^{* * *}$ & $-0.22^{* * *}$ & $-0.14^{* * *}$ \\
\hline Def & $-0.66^{* *}$ & 0.09 & $-0.28^{* *}$ & -0.35 & $-0.26^{* * *}$ & $-0.18^{*}$ \\
\hline Growth & 0.27 & 0.13 & $-0.19^{*}$ & $-0.29^{*}$ & $-0.14^{* *}$ & -0.05 \\
\hline OMT* Growth & -0.54 & $-0.58^{* * *}$ & $-0.36^{*}$ & 0.00 & 0.19 & $-0.24^{*}$ \\
\hline CA & $0.80^{* * *}$ & $0.34^{*}$ & $0.25^{*}$ & $0.49^{* * *}$ & -0.03 & $0.34^{* *}$ \\
\hline EPU & $0.05^{* * *}$ & 0.00 & $0.02^{* * *}$ & 0.02 & 0.00 & $0.02^{* *}$ \\
\hline
\end{tabular}

Note: ${ }^{* *}$ and ${ }^{* * *}$ denote significance at the $0.1,0.05$ and 0.01 level of significance.

Source: Our own calculations

Table 4 presents the results of estimation of the parameters of the panel variablecoefficient model. As it can be seen, in the first sub-period the estimate of the parameter for Debt variable is significantly positive for the "random" as well as "within" model in the case of Greece, Ireland, Portugal and Spain. Thus, the deterioration of the debt to GDP ratio in those countries was reflected in an increase in the spreads between their government bond yields and the yields of the corresponding German bonds. Only in the case of Italy, the impact of Debt on the spreads was insignificant. This could be due to the fact that despite the relatively high debt to GDP ratio in Italy, its growth in the period 2007Q3-2012Q2 amounted to "only" 18 percentage points, i.e. it was significantly lower than in the other countries of the analysed group. The significance of Debt variable in the corresponding period for the peripheral EMU economies has already been confirmed, among others, by 
Bernoth and Erdogan (2012), Beirne and Fratzscher (2013). In terms of the role of this variable in determining the spreads in the second sub-period, it proved to be insignificant (see Table 5). Based on the estimate of the parameter for the variable obtained for the first sub-period, the spreads should continue to grow after the second quarter of 2012. Meanwhile, in the period 2012Q3-2015Q3 the spreads decreased systematically. Given the above, it can be concluded that after the third quarter of 2012 there was a marked change in the sensitivity of the spreads to the debt-to-GDP ratio in the peripheral EMU countries.

Table 5 | Verification of the Hypothesis of the Sum of Parameters Measuring Impact of Variables on Spreads (P-values are given)

\begin{tabular}{|c|c|c|c|}
\hline \multicolumn{2}{|c|}{ Model } & $a_{1}+a_{1}^{*}=0$ & $a_{3}+a_{3}{ }^{*}=0$ \\
\hline \multicolumn{2}{|c|}{ random } & 0.23 & 0.07 \\
\hline \multirow{5}{*}{ within } & Greece & 0.18 & 0.14 \\
\hline & Ireland & 0.16 & 0.01 \\
\hline & Italy & 0.38 & 0.02 \\
\hline & Portugal & 0.36 & 0.09 \\
\hline & Spain & 0.32 & 0.23 \\
\hline
\end{tabular}

Source: Our own calculations

The impact of the second of the analysed fiscal variables included in the model, i.e. the projected general government balance, was negative. The significance of the estimate of the parameter for $D e f^{e}$ variable (at 0.1 ) in both sub-periods was confirmed for Greece, Italy and Spain.

Growth variable had a negative impact on the spreads. In the first sub-period, the rate of economic growth proved to be significant in the case of Italy, Portugal and Spain, while in the second sub-period - in the case of Ireland, Italy and Portugal. It is worth noting that the sensitivity of the spreads to the GDP growth rate was significantly stronger in the second sub-period (the estimate of the parameter for the "random" model was -0.05 in the period 2007Q3-2012Q2 and -0.29 in the period 2012Q3-2015Q3). The strongest impact of the analysed variable on the spreads was recorded in the second sub-period in the case of Ireland, which seems to reflect an improvement in investors' confidence in response to the high rate of economic growth in Ireland (which in 2014 amounted to 5.2\% $\mathrm{y} / \mathrm{y}$ and was the highest in the $\left.\mathrm{EU}^{3}\right)$. Infl variable proved to be insignificant, therefore it was not included in the final specification.

The impact of $C A$ variable on the spreads proved positive in the entire period. After 2009 , current account deficits in the analysed group of countries steadily decreased. It was not, however, a result of improvement of their competitiveness, but rather a result of the recession and the accompanying sharp decline in imports (the decline in the nominal value of imports for Greece, Portugal and Spain in 2008-2012 amounted to 34\%, 23\% and

3 The cited datum is derived from Eurostat. 
$22 \%$, respectively ${ }^{4}$ ). A similar result (positive estimate of the parameter for $C A$ variable in the spreads equation) was obtained in the study for Greece by Gibson et al. (2015).

$E P U$ variable had the same impact on the spreads in the two sub-periods. As expected, the estimate of the parameter for this variable was positive. The significance (at the level of 0.1) was confirmed for Greece and Italy. In the case of the first of these countries, uncertainty about the internal situation as well as the situation in its external environment was not conducive to the recovery of investors' confidence. In the case of Italy, it seems that along with the intensification of the crisis in the euro area concerns about the effects of contagion and, consequently, the need to seek financial assistance from the EU/IMF grew. At the same time, it has been pointed out that the resources of the EFSF/ESM are not sufficient to support the major EMU economies, such as Spain or Italy, should the need arise.

Referring to the ongoing debate in the literature on the causes of the sharp increase in government bond yields of the peripheral EMU countries, which started at the turn of 2009/2010, and the subsequent equally sharp decline, the findings of our study support the idea that the situation in the government bond market in the euro area was largely determined by non-fundamental factors (see e.g. De Grauwe and Ji, 2014; Saka, 2015). This is evidenced primarily by the estimate of the parameter for Debt variable in both sub-periods. The significance of this variable in the period preceding the introduction of the OMT programme and its absence in the second sub-period allow to draw the following conclusions. In the first sub-period, investors were sensitive to the deteriorating public finances of the peripheral EMU countries. Nevertheless, we cannot fully agree with Beirne and Fratzscher (2013) as well as Giordano et al. (2013) who explain this increase in sensitivity by the occurrence of the phenomenon of wake-upcall contagion. If it had been the only factor determining the situation in the government bond market in the euro area, there would not have been a sharp decline in the spreads of the peripheral EMU countries following the introduction of the OMT since, as has already been mentioned, their fiscal condition began to improve in 2014. Therefore, we conclude that macroeconomic fundamentals, primarily fiscal ones, had a significant impact on the evolution of the spreads, but only under conditions of uncertainty whether the ECB would enter into the role of LOLR for the governments. When the doubts in this regard were dispelled, investors' sensitivity to the debt-to-GDP ratio again proved to be insignificant (insignificance of Debt variable before the crisis was shown by e.g. De Grauwe, Ji, 2013). In other words, the phenomenon of the wake-up call contagion was "determined" by the lack of appropriate institutional arrangements in the euro area in the period 2007Q3-2012Q2.

In addition, a large impact of non-fundamental factors in determining the spreads is also confirmed by the significance of EPU variable in both sub-periods. At the same time, our results do not indicate that fundamental variables did not play any role. This is evidenced by significant, and in line with expectations, estimates of the parameters for $D e f^{e}, C A$ and Growth variables for some countries of the analysed group.

Knowing that the introduction of the OMT programme changed the sensitivity of the spreads to changes of various economic categories, we seek to verify how the spreads would have evolved in the second sub-period, if the OMT programme had not been introduced. 


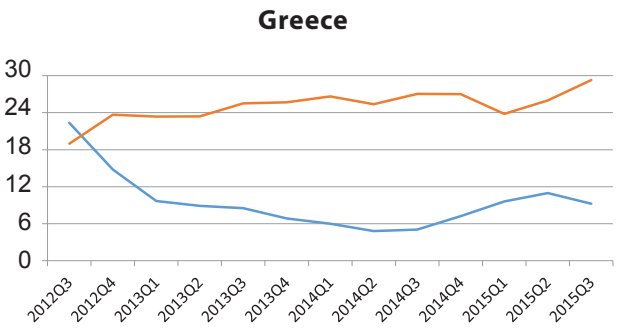

Italy

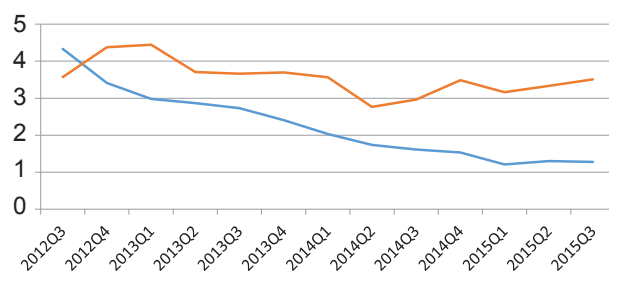

Spain

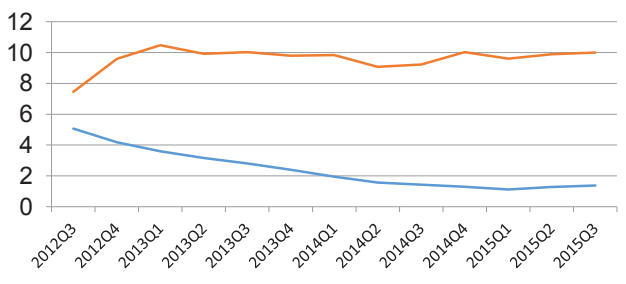

Ireland

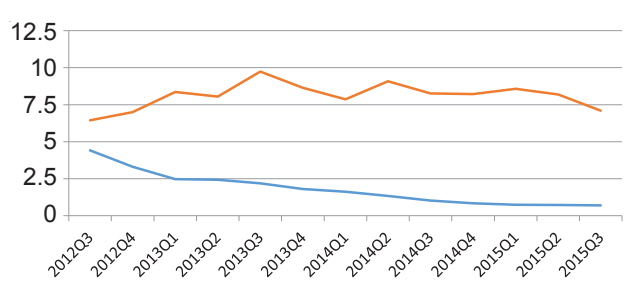

Portugal

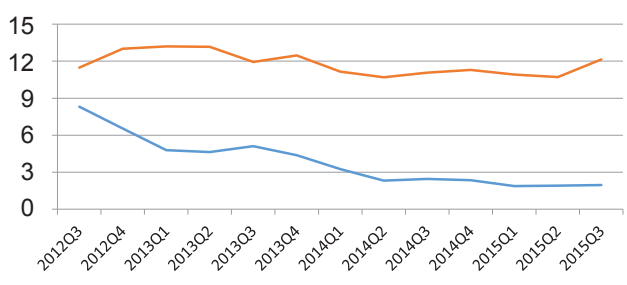

Source: Our own calculations.

In order to illustrate the quantitative effect of the ECB entering into the LOLR role for the governments on the spreads, theoretical values of dependent variable are calculated, assuming that the OMT variable is 0. A similar approach was applied by Favero (2013), who used the parameters estimates of the pre-crisis period (2000-2009) for the crisis period (2010-2012). Figure 2 shows the development of empirical and theoretical (assuming the absence of OMT programme after the second quarter of 2012) spreads. As it can be seen, thanks to the introduction of the OMT programme, the cost of servicing public debt in the peripheral euro area countries decreased. The largest differences relate to Greece. At the same time, the analysed differences are also evident in the case of Ireland, Portugal and Spain (amounting to approximately $6-8$ percentage points).

\section{Conclusions}

Since the turn of 2009/2010, there was a sharp rise in government bond yields of the peripheral euro area countries. The trend was reversed following the announcement of the OMT programme by the ECB in the third quarter of 2012. The situation in the government bond market in these countries since the beginning of the crisis has been the subject of numerous 
studies. In particular, attempts have been made to answer the question whether the spreads were determined by fundamental variables or other factors. Our research is part of this discussion, pointing to new aspects.

Our study was conducted based on data covering the period of more than three years since the announcement of the OMT programme. This enabled the estimation of the change in the sensitivity of the spreads in response to changes of some of macroeconomic variables after the announcement of the OMT programme compared to the crisis period preceding the event. In particular, we showed that the ratio of public debt to GDP, which significantly and strongly determined the spreads in the period 2007Q3-2012Q2, proved to be insignificant after the famous whatever it takes speech. This occurred despite the fact that the fiscal condition of the peripheral EMU countries continued to deteriorate until 2014. It seems, therefore, that the situation in the government bond market of the euro area resulted from the lack of institution of the lender of last resort to the governments, and was less dependent on fiscal factors. In addition, the counterfactual analysis conducted showed that the spreads would have been much higher if the ECB had not decided to introduce the OMT programme.

\section{References}

Aizenman, J., Hutchison, M., Jinjarak, Y. (2013). What is the Risk of European Sovereign Debt Defaults? Fiscal Space, CDS Spreads and Market Pricing of Risk. Journal of International Money and Finance, 34, 37-59, http://dx.doi.org/10.1016/j.jimonfin.2012.11.011

Alsakka, R., Gwiilym, O. (2013). Rating Agencies' Signals during the European Sovereign Debt Crisis: MARKET IMPACT and Spillovers. Journal of Economic Behavior \& Organization, 85, 144-162, http://dx.doi.org/10.1016/j.jebo.2011.12.007

Altavilla, C., Domenico, G., Michele, L. (2014). The Financial and Macroeconomic Effects of the OMT Announcements. ECB Working Paper, No. 1707. Available at: https://www.ecb.europa. eu/pub/pdf/scpwps/ecbwp1707.pdf

Arghyrou, M. G., Kontonikas, A. (2012). The EMU Sovereign-Debt Crisis: Fundamentals, Expectations and Contagion. Journal of International Financial Markets, Institutions \& Money, 22(4), 658-677, http://dx.doi.org/10.1016/j.intfin.2012.03.003

Bayomui, T., Goldstein, M., Woglom, G. (1995). Do Credit Markets Discipline Sovereign Borrowers? Evidence from the U.S. States. Journal of Money, Credit and Banking, 27(4), 1046-1059, http://dx.doi.org/10.2307/2077788

Beirne, J., Fratzscher, M. (2013). The Pricing of Sovereign Risk and Contagion during the European Sovereign Debt Crisis. Journal of International Money and Finance, 34, 60-82, http://dx.doi.org/10.1016/j.jimonfin.2012.11.004

Bernoth, K., Von Hagen, J., Schuknecht, L. (2012). Sovereign Risk Premiums in the European Government Bond Market. Journal of International Money and Finance, 31(5), 975-995, http://dx.doi.org/10.1016/j.jimonfin.2011.12.006

Bernoth, K., Erdogan, B. (2012). Sovereign Bond Yields Spreads: A Time-Varying Coefficient Approach. Journal of International Money and Finance, 31(3), 639-656, http://dx.doi. org/10.1016/j.jimonfin.2011.10.006

Bun, M. J. G. (2004). Testing Poolability in a System of Dynamic Regressions with Nonspherical Disturbances. Empirical Economics, 29(1), 89-106, http://dx.doi.org/10.1007/ s00181-003-0191-3. 
De Grauwe, P. (2012). Economics of Monetary Union. Oxford University Press, Oxford. ISBN: 978-0199605576.

De Grauwe, P., Ji, Y. (2013). Self-Fulfilling Crises in the Eurozone: An Empirical Test. Journal of International Money and Finance, 34, 15-36, http://dx.doi.org/10.1016/j. jimonfin.2012.11.003

De Grauwe, P., Ji, Y. (2014). The Future of the Eurozone. The Manchester School, 82, 15-34, http://dx.doi.org/10.1111/manc.12077

Falagiarda, M., Reitz, S. (2015). Announcements of ECB Unconventional Programs: Implications for the Sovereign Spreads of the Stressed Euro Area Countries. Journal of International Money and Finance, 53, 276-295, http://dx.doi.org/10.1016/j.jimonfin.2015.02.005

Favero, C. A. (2013). Modelling and Forecasting Government Bond Spreads in the Euro Area: a GVAR Model. Journal of Econometrics, 177(2), 343-356, http://dx.doi.org/10.1016/j. jeconom.2013.04.004

Gibson, H. D., Hall, S. G., Tavlas, G. S. (2014). Are All Sovereigns Equal? A Test of the Common Determinantion of Sovereign Spreads in the Euro Area. Empirical Economics, 48(3), 939-949, http://dx.doi.org/10.1007/s00181-014-0825-7

Giordano, R., Pericoli, M., Tommasino, P. (2013). Pure or Wake-up Call Contagion? Another Look at the EMU Sovereign Debt Crisis. International Finance, 16(2), 131-160, http://dx.doi. org/10.1111/j.1468-2362.2013.12033.x

Kilponen, J., Laakkonen H., Vilmunen J. (2015). Sovereign Risk, European Crisis Resolution Policies and Bond Spreads. International Journal of Central Banking, 11, 285-323. Available at: http://www.ijcb.org/journal/ijcb15q2a8.pdf

Louzek, M. (2015). Eurozone Crisis. Prague Economic Papers, 24(1), 88-104, http://dx.doi. org/10.18267/j.pep.502

Oliveira, L., Curto, J. D., Nunes, J. P. (2012). The Determinants of Sovereign Credit Spread Changes in the Euro-Zone. Journal of International Financial Markets, Institutions and Money, 22(2), 278-304, http://dx.doi.org/10.1016/j.intfin.2011.09.007

Pedroni, P. (2001). Purchasing Power Parity Tests in Cointegrated Panels. Review of Economics and Statistics, 83(4), 727-731, http://dx.doi.org/10.1162/003465301753237803

Saka, O., Fuertes, A. M. Kalotychou, E. (2015). ECB Policy and Eurozone Fragility: Was De Grauwe Right? Journal of International Money and Finance, 54, 168-185, http://dx.doi. org/10.1016/j.jimonfin.2015.03.002

Swamy, P. A. (1970). Efficient Inference in a Random Coefficient Regression Model. Econometrica, 38(2), 311-332, http://dx.doi.org/10.2307/1913012

Winkler, A. (2015). The ECB as Lender of Last Resort: Bank versus Governments. Journal of Economics and Statistics, 235(3), 329-341, http://dx.doi.org/10.1515/jbnst-2015-0307 